\title{
ЗАЩИТА ПРАВ ЧЕЛОВЕКА ОТ МОРАЛЬНОГО ВРЕДА В УГОЛОВНОМ ЗАКОНОДАТЕЛЬСТВЕ ТАДЖИКСКОЙ ССР
}

\author{
Зокирзода Зафар Хайрулло \\ кандидат юридических наук
} доцент кафедры права и методики его преподавания

Бобохонов Фаридун Аламшоевич старший преподаватель кафедры права

и методики его преподавания Педагогический институт Таджикистана в Раштском районе

Аннотация: в статье рассматривается защита прав человека от морального вреда в уголовном законодательстве Таджикской ССР. Авторы утверждают, что важнейшие духовные ценности человека, такие как жизнь, здоровье, честь, достоинство, свобода совести и религии, деловая репутация и т.д., охранялись в соответствии с уголовным законодательством Таджикской ССР. Авторы подробно рассмотрели уголовно-правовую защиту прав человека от морального вреда в Таджикской ССР и пришли к выводу, что в советской правовой системе уголовное право устанавливает строгие нормы защиты прав человека от морального вреда, в том числе клеветы, оскорбления и т.п.

Ключевые слова: защита, права человека, моральный вред, нематериальные блага, уголовное законодательство, Таджикская ССР.

\section{PROTECTION OF HUMAN RIGHTS FROM MORAL DAMAGE IN THE CRIMINAL LEGISLATION OF THE TAJIK SSR}

\section{Zokirzoda Zafar Khairullo Bobokhonov Faridun Alamshoevich}

\begin{abstract}
: the article deals with the protection of human rights from moral harm in the criminal legislation of the Tajik SSR. The authors argue that the most important spiritual values of a person, such as life, health, honor, dignity, freedom of conscience and religion, business reputation, etc., were protected in accordance with the criminal legislation of the Tajik SSR. The authors examined in detail the criminal legal protection of human rights from moral harm in the Tajik SSR and came to the
\end{abstract}


conclusion that in the Soviet legal system, criminal law establishes strict norms for the protection of human rights from moral harm, including slander, insults, etc.

Key words: protection, human rights, moral harm, intangible benefits, criminal law, Tajik SSR.

Вопрос защиты прав человека от морального вреда является одним из межотраслевых вопросов в области конституционного, уголовного, гражданского, семейного и трудового права, и в ходе истории именно в советском праве возникли отраслевые правовые акты. Поэтому уместно поставить вопрос о защите прав человека от морального вреда в уголовном законодательстве Таджикской ССР.

Одним из таких отраслей права, предусматривающим защиту прав человека от морального вреда в широком виде, является область уголовного права. Профессор У.А. Азизода разделил становление уголовного права в советской правовой системе на два этапа: 1) от революционных событий до

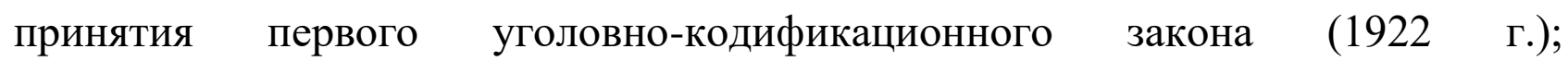
2) кодификация уголовного права на общесоюзном и республиканском уровнях [1, с. 189-190]. В другом месте исследователь отмечает, что в советском законодательстве уголовное наказание понималось как «контрреволюционные репрессии» и уничтожение групп басмачей было выражено [5, с. 189]. В первые годы советской власти существовало множество нормативных актов, касающихся преступлений и наказаний [7, с. 19]. Следует отметить, что одним из видов наказания является реабилитация, а в случае невозможности возмещение ущерба [1, с. 196].

Одним из законодательных актов, защищавших права человека от морального вреда после 1920-х годов, был Уголовный кодекс СССР, принятый 24 мая 1922 года, а 21 июня 1922 года решением ЦИК УПК РФ на территории УПК вступил в силу Уголовный кодекс РСФСР [1, с. 199]. В этот период задача уголовного права была направлена не только на борьбу с басмачами и антиреволюционными движениями, но и на тех, кто совершил преступления, посягающие на ценности, охраняемые уголовным правом. В этот период наиболее опасными преступлениями были попытки самоубийства, нарушения здоровья, имущественных прав граждан и т.п. [3, с. 189].

9 мая 1935 года решением Президиума Совета ЦИК Таджикской ССР был принят Уголовный кодекс Таджикской ССР, сыгравший важную роль в дальнейшей защите прав человека от морального вреда. Большую роль в 


\section{КОНСОЛИДАЦИЯ ИНТЕЛЛЕКТУАЛЬНЫХ РЕСУРСОВ КАК ФАКТОР РАЗВИТИЯ СОВРЕМЕННЫХ ИССЛЕДОВАНИЙ}

становлении и развитии уголовного права Таджикской ССР сыграл Уголовный кодекс Таджикской ССР 1935 года, при поддержке ряда исследователей, таких как У.А. Азизов [1, с. 235], М.М. Муллаев [11, с. 122-123]. Следует отметить, что Уголовный кодекс установил справедливую ответственность за уголовное законодательство зороастрийской и мусульманской правовых систем. Потому что по зороастрийскому и мусульманскому праву уголовные наказания были суровыми и наносили телесные повреждения. Как отмечает исследователь У.А. Азизода Уголовный кодекс Таджикской ССР 1935 года не считает своим долгом причинение телесных повреждений или оскорбление человеческого достоинства [1, с. 240]. Эту точку зрения М.М. Муллаев также поддержал, добавив, что в соответствии с советским уголовным законодательством нанесение телесных повреждений не считалось уголовным преступлением $[12$, c. 77$]$.

Глава 7 Уголовного кодекса Таджикской ССР 1935 года, которая варьировалась от статей 168 до 194, была направлена на защиту прав человека от морального вреда. В этой главе были защищены нематериальные блага человека. В том числе жизнь, здоровье, достоинство гражданина. Глава состоит из пяти разделов, охватывающих следующие вопросы: первый раздел, ответственность за преступления против жизни - убийства, самоубийства и аборты; второй раздел - ответственность за преступления против здоровья на всех уровнях, изнасилование; третий раздел о сексуальных преступлениях; четвертый раздел уголовная ответственность за угрозу; пятая глава посвящена нападкам на его личность и достоинство (клевета и оскорбление) [1, с. 249]. Отсюда следует делать вывод, что Уголовный кодекс 1935 года уделял особое внимание защите прав человека от морального вреда и признавал деяния морального вреда преступным деянием. В частности, клевета и оскорбление, являющиеся одним из наиболее тяжких действий с причинением морального вреда, по-прежнему считались в Таджикской ССР уголовно-наказуемыми деяниями, и за их совершение устанавливалась уголовная ответственность.

25 декабря 1958 г. было принято Основное уголовное законодатедьство Союза ССР и союзных республик, а с 1959 по 1961 г. - Уголовные кодексы союзных республик. При этом в 1961 году Уголовный кодекс Таджикской ССР был повторно принят, и этот новый этап считался защищающим права человека от морального вреда. В связи с тем, что международные дркументы повлияли на защиту прав и свобод человека, были ужесточены уголовные наказания за нарушение личных прав [10, с. 64]. Некоторые уголовные преступления, 
включая покушение на убийство, умышленное причинение телесных повреждений, клевету и т.П., наказываются смертью [10, с. 66]. У.А. Азизов отмечает, что в Уголовном кодексе Таджикской ССР 1961 года была предусмотрена отдельная глава, посвященная защите жизни, здоровья и достоинства личности [1, с. 257]. Конечно, это свидетельствует о том, что даже в Советском Таджикистане вопросу защиты прав человека от морального вреда уделялось особое внимание.

Третья глава Уголовного кодекса Таджикской ССР 1961 года предусматривала преступления против жизни, здоровья, свободы и достоинства личности и содержала 39 статей. В частности, от статьи 104 до статьи 110 различные формы убийства, от статьи 111 до статьи 120 - различные формы причинения вреда здоровью, от статьи 121 до статьи 125 - различные формы сексуальных преступлений, от статьи 126 до статьи 134 - различные формы семейных преступлений, от статьи $134^{1}$ до статьи 139 статьи были установлены различные формы преступлений против свободы и достоинства личности [13, с. 81-94]. Статьей 138 этого Кодекса предусмотрено одно из деяний с причинением морального вреда - клевета. Это форма клеветы, то есть умышленное распространение ложной информации, носящей клеветнический характер. Такое деяние каралось лишением свободы, штрафами, исправительными работами, общественным выговором или общественными работами [13, с. 94]. В то же время статья 139 предусматривает оскорбления, в том числе словесные, письменные или оскорбления с движениям. Наказание за такой поступок заключалось в исправительных работах, штрафах и мерах общественного воздействия [13, с. 94]. Эти нормы стали новым и большим шагом в защите прав человека от морального вреда. Но ответственность за такие действия очень легкая. Следует отметить, что Уголовный кодекс Таджикской ССР 1961 года применялся до принятия постсоветского Уголовного кодекса Республики Таджикистан в 1998 году. После его принятия были приняты многочисленные законы о внесении в него поправок, что свидетельствует о дальнейшем развитии институтов уголовного права в Таджикистане [3, с. 246]. Следует отметить, что защита прав человека от морального вреда уголовными нормами имеет исторический характер и реализовывалась в историко-правовых системах, в том числе в зороастрийской правовой системе [4], мусульманской правовой системе [6], современной таджикской уголовно-правовой системе. Права человека также защищены от морального вреда [8]. Следует отметить, что современное уголовное 


\section{КОНСОЛИДАЦИЯ ИНТЕЛЛЕКТУАЛЬНЫХ РЕСУРСОВ КАК ФАКТОР РАЗВИТИЯ СОВРЕМЕННЫХ ИССЛЕДОВАНИЙ}

законодательство Таджикистана, в отличие от историко-правовых систем, особенно советского права, не защищает человеческое достоинство от клеветы и оскорбления. В связи с этим несмотря на то, что законодательство страны и международные акты предусматривают защиту человеческого достоинства и чести, но в Республике Таджикистан гражданско-правовые средства защиты священных и неотъемлемых прав человека от клеветы и оскорблений недостаточны и неэффективны. Такая защита прав человека не предотвратит в будущем клевету и оскорбления. Поэтому декриминализация клеветы и оскорбления преждевременна, а их повторная криминализация ведет к совершенствованию уголовного законодательства и защите священных прав и свобод человека. Таким образом, исходя из вышеуказанных правовых оснований, мы предлагаем повторно признать клевету преступлением и усилить ответственность за нее (ст. 135 УК РТ) [9, с. 22].

Таким образом, советская правовая система со своим законодательством, отраслевыми институтами и спецификой действовала в Таджикистане до принятия УК 1998 года. После его принятия были приняты многочисленные законы о внесении изменений в закон, что свидетельствует о дальнейшем развитии уголовно-правовых институтов в Таджикистане [3, с. 246].

В ходе анализа и исследования данной темы мы пришли к следующим выводам:

1. В начале советской эпохи права и свободы человека не были должным образом реализованы, но теоретически их правовые акты в той или иной степени регулировали различные права человека. Нельзя сказать, что в начале советской эпохи прав человека не существовало или вообще не соблюдалось. Потому что каждый исторический период со своими особенностями регулирует и защищает права и свободы человека.

2. Уголовный кодекс Таджикской ССР 1935 г. установил справедливую ответственность по уголовному праву зороастрийской и мусульманской правовых систем. Потому что в зороастрийском и мусульманском праве уголовные наказания носили суровый характер (телесные наказания, побивание камнями и т.д.). Наказания не были предусмотрены Уголовным кодексом Таджикской ССР 1935 года.

3. В результате исследования установлено, что важнейшие духовные блага человека, такие как жизнь, здоровье, честь, достоинство, свобода совести и вероисповедания, деловая репутация и т.п, охранялись в уголовном законодательстве Таджикской ССР. В советской правовой системе уголовным 
законодательством были установлены строгие правила защиты прав человека от морального вреда, в том числе клеветы, оскорбления и т.п.

4. В отличие от историко-правовых систем, особенно советского права, современное уголовное законодательство Таджикистана не предусматривает защиты человеческого достоинства от клеветы и оскорбления.

\section{Список литературы}

1.Азизов, У.А. Эволюция институтов преступления и наказания на территории исторического и современного Таджикистана: историко-правовое исследование: монография[Текст] / У.А. Азизов. - Душанбе: Андалеб-Р, 2015. $368 \mathrm{c}$.

2.Азизов, У.А. Влияние религиозных норм на формирование и развитие основных институтов уголовного права таджикистана. Вестник Таджикского национального университета[Текст] / У.А. Азизов // Научный журнал. Социально-экономические и социальные науки. - 2017. - №2/10. - С. 245-251.

3.Азизов, У.А. Становление и развитие уголовного законодательства на начальном этапе строительства советского государства в таджикистане [Текст] / У.А. Азизов // Паёми Донишгохи миллии Точиикстон // Мачаллаи илмй. Бахши илмхои ичтимой-иқтисодй ва чамъиятй. - 2017. - №2/3. - С. 188-193.

4.Азиззода, У.А., Бобохонов Ф.А. Защита прав человека от клеветы и оскорбления в зороастрийской правовой системе [Текст] / У.А. Азиззода., Ф.А. Бобохонов // Вестник Таджикского национального университета / Серия социально-экономических и общественных наук. - 2020. - №5. - С. 254-262.

5. Азиззода, У.А., Бобохонов Ф.А. Защита прав человека от морального вреда в советской правовой системе [Текст] / У.А. Азиззода., Ф.А. Бобохонов // Вестник Филиала Московского государственного Университета имени М.В. Ломоносова в городе Душанбе / Серия гуманитарных и экономических наук. - 2021. - №2 (18). - 50-64.

6.Бобохонов, Ф.А. Защита прав человека от клеветы в мусульманской правовой системе [Текст] / Ф.А. Бобохонов // Вестник Педагогического института Таджикистана в Раштском районе. - 2021. - №2(6). - С. 127-132.

7.Зокирзода, 3.X. Мусодираи молу мулк хамчун намуди чазои чиноятй[Матн]: дис. ... ном. илм. хукуқ: 12.00.08. / 3.Х. Зокирзода. - Душанбе, 2020. $-176 \mathrm{c}$. 
8.Зокирзода, 3.Х., Бобохонов, Ф.А. Защита прав человека от морального вреда в уголовно-правовых отношениях [Текст] / 3.Х. Зокирзода., Ф.А. Бобохонов // Вестник Таджикского национального университета / Серия социально-экономических и общественных наук. - 2021. - №4. - С. 220-228.

9.Зокирзода, 3.Х., Бобохонов, Ф.А. Криминализация и декриминализация клевета в Республике Таджикистан[Текст] / З.Х. Зокирзода., Ф.А. Бобохонов // Правовая позиция. - 2021. - №9. - С. 15-25.

10.Курляндский, В.И. Уголовная ответственность и меры общественного воздействия. - М., 1965. - 142 с.

11.Муллаев, М.М. История уголовного права Таджикской ССР[Текст] / М.М. Муллаев. - Сталинобод, 1960. - Ч.1. - С. 159 с.

12.Муллаев, М.М. Коментарии к Уголовному Кодексу Таджикской ССР (Общая часть) [Текст] / М.М. Муллаев. - Душанбе, 1969. - 258 с.

13.Уголовный кодекс Таджикской ССР 1961 г. с изменениями и дополнениями от 1 июня 1988 г. - Душанбе: “Ирфон”, 1989. - 203 с 